\title{
"CASO BOMBAS": DISCURSOS SOBRE EL ANARQUISMO EN CHILE
}

\author{
Francisca E. Beroiza Valenzuela ${ }^{(a)}$
}

"CASO BOMBAS": DISCOURSES ON ANARCHISM IN CHILE

"CASO BOMBAS": DISCURSOS SOBRE O ANARQUISMO NO CHILE

Fecha de recepción: 22 de abril del 2020

Fecha de aprobación: 9 dejunio del 2020

Disponible en línea: 25 de septiembre del 2021

\section{Sugerencia de citación:}

Beroiza, F. (2021). “Caso Bombas”: discurso sobre el anarquismo en Chile. Razón Crítica, 10, 237-274. https://doi.org/10.21789/25007807.1681

(a) Francisca E. Beroiza Valenzuela

Licenciada en Educación, Magíster en Historia, mención Historia de Chile,

Universidad de Santiago de Chile.

Profesora de educación general básica con mención en lenguaje, comunicación y comprensión del medio social, Chile.

https://orcid.org/0000-0003-2424-1207

francisca.beroiza@usach.cl 


\section{R E S U M E N}

Este artículo analiza el tratamiento que los diarios $\mathrm{La}$ Segunda, El

Ciudadano y el Poder Ejecutivo y Legislativo de Chile, le otorgaron a la relación entre el "Caso Bombas" y los grupos anarquistas desde agosto del 2010 a junio del 2012. La hipótesis sostiene que visibilizar un tipo de ejercicio de violencia, relacionado con la utilización de explosivos para manifestar una crítica por parte de grupos asistémicos, ha generado una respuesta estatal y de los medios de opinión que cataloga a estos grupos como anarquistas con orientaciones terroristas, negando sus especificidades. Desde la perspectiva metodológica del análisis crítico del discurso de Norman Fairclough, se busca distinguir un sesgo criminalizador de ciertos actores sociales hacia grupos marginales.

PALABRAS CLAVE: anarquismo; discurso; terrorismo; violencia política. 


\section{A B S T R A C T}

This work examines the treatment that La Segunda and El Ciudadano newspapers and the Chilean executive and legislative powers gave to the relationship between the "Caso Bombas" and anarchist groups in this country from August 2010 to June 2012. The hypothesis proposes that the fact of highlighting this type of exercise of violence - related to the use of explosive devices to express criticism by non-organized groupshas produced a response from the State and the media that categorizes these groups as anarchists with terrorist orientations, thus denying their specificities. From the methodological perspective of Norman Fairclough's critical analysis of the discourse, this study seeks to distinguish a criminalizing bias of certain social actors towards marginal groups.

KEYWORDS: anarchism; discourse; terrorism; political violence.

\section{R E S U M O}

Este artigo analisa o tratamento que os jornais La Segunda e El Ciudadano, bem como o Poder Executivo e Legislativo do Chile dão à relação entre o "Caso Bombas" e os grupos anarquistas desde agosto de 2010 a junho de 2012. A hipótese é de que visibilizar um tipo de exercício de violência, relacionado com a utilização de explosivos para manifestar uma crítica por parte de grupos assistêmicos, gera uma resposta do Estado e dos meios de opinião que cataloga esses grupos como anarquistas com orientações terroristas, negando suas especificidades. Sob a perspectiva metodológica da análise crítica do discurso de Norman Fairclough, busca-se identificar uma tendência criminalizadora de certos atores sociais a grupos marginais.

PALAVRAS-CHAVE: anarquismo; discurso; terrorismo; violência política. 


\section{N T R O D U C C I Ó N}

Las estadísticas chilenas señalan que desde el 2004 hasta la fecha (2012), habrían estallado más de 71 artefactos explosivos (Instituto Libertad y Desarrollo, 2012), de los cuales, a pesar de las investigaciones realizadas por la Fiscalía Metropolitana Oriente a cargo del Juez, Xavier Armendáriz, se desconocía la autoría y no había detenidos. A este hecho se le denominó nacionalmente como "Caso Bombas".

El 22 de mayo del 2009 el militante anarquista Mauricio Morales, falleció instantáneamente cuando explotó la bomba que traía consigo en su mochila, en cercanías de la Escuela de Gendarmería en Santiago de Chile. Este acontecimiento conmocionó a la opinión pública, y centró la atención en el movimiento anarquista del país, lo cual interpeló al Ministerio del Interior a efectuar una investigación para dar con los culpables de estos atentados, señalados por ellos como "asociación ilícita terrorista” (Fiscalía Regional Metropolitana Sur, 2012). El 12 de junio del 2010, estalló otra bomba en una sucursal de BancoEstado, situada en Avenida Las Condes \#11.550, a tres cuadras de la casa del Presidente de la República, Sebastián Piñera, acción que se adjudicó al Comando Insurreccional Andrés Soto Pantoja.

Ya que no habían procesados por esta investigación y en vista de las presiones del Gobierno, el Fiscal Nacional, Sabas Chahúan, despojó del caso a la Fiscalía Metropolitana Oriente (Tamayo, 2012), y entregó el Caso Bombas a la Fiscalía Metropolitana Sur a cargo del fiscal, Alejandro Peña. Más adelante, el 14 de agosto del 2010, en el marco de la denominada "Operación Salamandra", se realizaba un allanamiento a 17 viviendas en la Región Metropolitana y de Valparaíso, lo que equivalió a 
la irrupción mediática de las casas Okupa: "La Crota", ubicada en la Calle Santa Isabel \#380 comuna de Providencia; "Sacco y Vanzetti”, situada en Santo Domingo \#2423 en Santiago Centro; el "Centro Social Autónomo y Biblioteca Libertaria Jonny Cariqueo”, en El Cobre \#8793 comuna de Pudahuel; la "Casa Ocupada La Escalera”, ubicada en Erasmo Escala N. 2420 comuna de Santiago; y a la "Casa La Idea", ubicada en Rafael Sotomayor N. 449 comuna de Santiago, entre otras (Tamayo, 2012). En total, se detuvieron a 14 personas, acusadas de ser las responsables de haber sembrado el terror en la población chilena. En adelante, se desarrollaría una estrategia comunicacional por parte del Estado, avalado por la prensa escrita, en la que se haría un tratamiento sobre el anarquismo en Chile como una forma de desdibujar la imagen de un movimiento social. Por tal razón, este texto se plantea la siguiente pregunta de investigación como guía ¿Por qué se focalizó el Caso Bombas en los anarquistas? Y ¿Cuál es la particularidad del discurso incriminatorio del Estado y de algunos medios respecto al anarquismo del Caso Bombas?

La hipótesis que plantea este trabajo señala que ante la emergencia de visibilizar un tipo de ejercicio de la violencia, relacionado con la utilización de explosivos para manifestar una crítica al marco político, social, económico y cultural en Chile por parte de grupos o individuos asistémicos, se ha generado una respuesta estatal y de los medios de opinión pública que los cataloga como anarquistas con orientaciones terroristas, negando las especificidades que permiten establecer su identidad. A pesar de la generalización que realizan tanto el Estado como los medios de opinión pública, el tipo de individuos y grupos vinculados a estas acciones tienen características diversas por lo que su categorización homogénea tiende a desdibujar su identidad y a dificultar la aprehensión de su discurso.

En ese sentido, el objetivo de este estudio es analizar el tratamiento del anarquismo en Chile en relación al Caso Bombas, por lo cual es necesario precisar la definición de anarquismo socialmente construida, caracterizar y comparar la relación establecida entre anarquista y terrorista, así como también distinguir si se determinaron particularidades de los grupos vinculados al caso. Para lograr dicho objetivo, se analizará la prensa escrita, específicamente de los diarios La Segunda y El Ciudadano, también en los discursos del Ministro del Interior, representantes de la Cámara de Diputados y Senadores desde el mes de agosto del 2010 hasta junio del 2012, mes en el que se absolvió a los acusados. A la luz de la hipótesis de esta investigación, se vislumbrarán casi dos años de estos discursos. 
La producción investigativa que se ha formulado en relación al Caso Bombas y al anarquismo en el siglo xxi es insuficiente. Una de las primeras investigaciones sobre el Caso Bombas, se encuentra desde el ámbito del periodismo en el 2011 con las investigadoras Sue Carrié, Katherine Lorca y Katherine Torres, en la cual plantean que los medios de prensa contribuyen a adjudicar a sectores sociales minoritarios comportamientos sociales negativos, lo que advierte una tendencia de criminalizar en la entrega informática. Por su parte, en el 2012, Tania Tamayo, postuló la tesis del abandono de las funciones públicas del cuarto poder, es decir la prensa. Ese mismo año, el sociólogo Alberto Mayol, se refirió al Caso Bombas como un ejemplo de concentración de los poderes soberanos, donde se intentó tener un control implícito y explícito sobre el poder judicial, al politizar el caso. A su vez, en el 2013 se tiene la visión desde la psicología política del investigador, Juan Silva, la cual postula que a través del empleo de las tecnologías Psi, los medios escritos La Tercera y El Mercurio entre mayo del 2010 y agosto del 2010, criminalizaron los discursos de la violencia y las prácticas de resistencia política contribuyendo a la situación de dominación.

En cuanto a la literatura e investigaciones sobre el anarquismo en el siglo xxi, uno de los primeros textos que se publicó en el 2001, fue el libro Bitácora de la Utopía: anarquismo para el siglo XXI de Nelson Méndez y Alfredo Vallota, el cual otorga una mirada sobre los desafíos que tiene el anarquismo en este siglo xxi para forjar un futuro promisorio. Su tesis se orienta a que ante un mundo de desigualdades, surgen propuestas que se guían a la construcción de un mundo anarquista. Más adelante, en el 2007, Tomás Ibáñez en su texto La actualidad del anarquismo, realiza una crítica al contexto en que se está ideando el anarquismo en la actualidad. Uno de los aspectos tratados, es la crítica hacia lo que se denomina "centro", como una metáfora de poder hegemónico que coarta y domina, el cual debe ser atacado, no sin antes renovar las bases del anarquismo.

Luego, en el 2011 se publicó Un anarquismo para el siglo XXI del sociólogo Alfredo Errandonea, que realiza un análisis crítico sobre el anarquismo como un movimiento antiestatista y antiautoritario que se proponía cambiar la sociedad. Para el autor, se debe volver a las fuentes, a la revisión teórica y doctrinaria, reivindicándose la participación y militancia de esta ideología para reducir la dominación. También se publicó el texto Pensar las autonomías, que cuenta con los aportes de Ezequiel Adamovsky, Claudio Albertani, entre otros, en el que se plantea que en esta sociedad capitalista, con un contexto humillante, alienante, de 
empleos que reproducen y multiplican la subordinación, se debe politizar la vida para crear una sociedad sin hegemonías.

Uno de los últimos estudios publicado en el 2013 es del profesor en Ciencias Políticas de la Universidad de Yale, James C. Scott, titulado Elogio al anarquismo, en cual desarrolla una investigación de larga data sobre el anarquismo, señalando la dominación autoritaria del Estado sobre la vida privada y pública de los individuos. Ese mismo año, la historiadora Pamela Quiroga, plantea que en décadas de desencanto y malestar el anarquismo constituyó una vía de politización no exenta de contradicciones, carencias y límites, generó nuevas formas de participación que al tomar distancia de las instituciones, encontró en el anarquismo una fuente de inspiración.

Ahora bien, para efectos de este estudio se utilizaron las siguientes categorías conceptuales: anarquismo, violencia política y terrorismo.

\section{ANARQUISMO}

El nacimiento del anarquismo y su configuración como filosofía social e ideología, se dio en la primera mitad del siglo xıx; y al igual que el marxismo, en el contexto de Revolución francesa, en la que asciende una clase burguesa y se forma la clase obrera, haciéndose notorias las desigualdades. En la actualidad, se suele asociar la "amenaza terrorista", con grupos asistémicos, tildándolos específicamente como "anarquistas", en ese sentido, resulta imperioso conocer el fundamento de este movimiento, con el fin de entender sus características y dilucidar su presencia en la sociedad del siglo XXI.

Para Errico Malatesta, "la palabra Anarquía procede del griego y significa 'sin gobierno'; es decir, el estado de un pueblo que se rige sin autoridad constituida, sin gobierno" (Malatesta, 1975, p. 188). Sin embargo, anarquismo, no significa ausencia o negación del orden o poder, sino que como lo señala Ángel Capelletti, “quiere decir únicamente negación del poder permanente y de la autoridad instituida o, en otras palabras, negación del Estado" (Cappelletti, 1985, p. 8).

El anarquismo, como todo cuerpo teórico y práctico, tiene objetivos específicos que rigen su actuar, tal cual como lo manifiesta Félix García Moriyón, para ellos se debe "transformar la sociedad, o de hacer del presente un modo diferente de ver, juzgar y actuar... conviene alcanzar la mayor eficacia posible y eso exige ciertos niveles de colaboración y coordinación” (García, 2009, p. 14). Los anarquistas, no luchan contra 
cualquier fuerza, sino que uno de sus principales ataques es el Estado, porque "este representa la máxima concentración del poder" (Cappelletti, 1985, p. 10). Asimismo, como lo señala Sébastien Faure, uno de los principales artífices de la Enciclopedia anarquista, en 1972 en la sociedad la autoridad reside en tres formas principales: Estado, capital y religión, que son la forma del poder político, económico y moral por las cuales el individuo lucha.

De este modo, el anarquismo se constituye como un peligro para los tres poderes hegemónicos, pues pretende irrumpir y abolir esas formar de dominación. Es una postura revolucionaria, no es una acción desorganizada, ni superflua de componentes teóricos, sino que "en cuanto representan una posición ético-política que traduce un sentimiento de rebelión frente al poder en general [...] podría decirse que tales ideas 'anarquistas' son universales” (Cappelletti, 1985, p. 10). El dilema está en que para estos tres poderes, no es conveniente su carácter de universalidad. Por ello, los anarquistas requieren que el sujeto "acepte la sujeción, y sí la represión, que ya no puede ser exterior, es interiorizada por cada participante [...] el anarquismo exige de los individuos un yo fuerte que admita una libre autodisciplina" (Ansart, 1970, p. 241). No obstante, para los fines anarquistas, el individuo no está acostumbrado a vivir y estar en libertad, puesto que como bien manifiesta Étienne de La Boétie en $E l$ discurso de la servidumbre voluntaria (1574), citado en Ansart (1970):

Los hombres prescinden muy fácil y prontamente de su libertad. La primera causa de ello es la costumbre. Quienes han nacido bajo la tiranía, al ignorar lo que es la libertad, se someten [...] La segunda causa de la pérdida de la libertad es el envilecimiento y la cobardía que el poder tiránico produce en el pueblo [...] La tercera causa del sometimiento, es el miedo a lo desconocido y el terror ante el misterio (p. 241).

En el ser humano se ha instalado una servidumbre voluntaria, que le impide vislumbrar el valor de la libertad. Se podría aventurar una analogía, en lo que posteriormente el sociólogo Pierre Bourdieu denominaría "violencia simbólica", que se nutre de los "sistemas simbólicos" para legitimarse, los cuales cumplen una función política de instrumentos de imposición de la dominación, que contribuiría a asegurar la dominación de la clase sobre otra, aportando el refuerzo de su propia fuerza a las relaciones de fuerza que las fundan (Bourdieu, 2012). En esta 
lógica de dominación, surge el interrogante sobre ¿Cómo se lleva a cabo el propósito anarquista? Este movimiento con el objetivo de formar seres humanos libres, no funciona sin sus pilares ideológicos de igualdad y solidaridad. La solidaridad es esencial para la victoria de los fines que se persiguen, y es un aspecto que los distingue del panorama de la sociedad posmoderna, con un individualismo consolidado, como lo apunta Piotr Kropotkin, en la sociedad es un hecho la lucha por la existencia, y la igualdad desarrolla un papel fundamental. Ambos pilares ideológicos, son las armas que se emplean para luchar en pro de este objetivo que es la libertad. "Esta sociedad de hombres libres, esta sociedad de personas solidarias y fraternas, esta sociedad de amigos, es lo que representa la anarquía” (Kropotkin, 2008, p. 33).

Según se ha planteado en términos organizativos, el anarquismo corresponde a:

Grupos y organizaciones que dan gran importancia a la participación y el protagonismo de los implicados, evitando la monopolización o dirección del movimiento por unas minorías [...] muestran formas organizativas de tipo asambleario y autogestionario [...] para que la gente pueda recuperar ese protagonismo y ese papel de sujetos activos de la historia que con frecuencia les es arrebato [...] se tiene el convencimiento de que el objetivo es alcanzar un mundo más solidario (García, 2009, p. 12)

Un aspecto trascendental es la militancia en el anarquismo, puesto que garantiza una mayor capacidad e intervención, desencadena mayor activismo y participación en el movimiento, lo cual es fundamental para terminar con esos poderes coercitivos y efectuar su razón última que se orienta al "derrumbe del Estado" (Bakunin, citado en Mintz, 2006), y el surgimiento de una sociedad libertaria. Por ello, en el caso chileno en la última década podemos "apreciar vinculaciones con el anarquismo que comienzan a depurarse. Colectivos, organizaciones, publicaciones y experiencias siguen desarrollándose bajo el alero de lo 'libertario' o en la búsqueda hacia 'lo libertario'” (Quiroga, 2013, p. 70). En ese aspecto, las organizaciones han preferido el concepto de libertario "antes que el de anarquismo, que estaría asociado a un impulso o sentimiento inspirado por el anarquismo, pero asumido de forma más intuitiva que ideológica” (Álamos, 2009, citado por Quiroga, 2013, p. 16). Por lo que los movimientos, organizaciones y las subsecuentes protestas, no 
son expresión ideológica a priori del anarquismo, sino que se han nutrido de las experiencias o principios de este.

Por otro lado, en Chile se ha vivido un proceso que se ha denominado “politización”, abriéndose a espacios de movilización y cuestionamiento de elementos estructurales del sistema neoliberal. Algo cambió en las lógicas políticas de los jóvenes, pero también en otros sectores sociales, con una crítica "más radical y a una forma de organización menos jerárquica y muchas veces por fuera de los partidos tradicionales, lo que en varios niveles era coherente con lo promovido por el anarquismo" (Quiroga, 2013, p. 85). Consideramos que, para entender el anarquismo en el siglo XXI, es necesario conocer sus pilares ideológicos, su sustrato epistemológico, que si bien ha cambiado en el tiempo, ha mantenido su razón primera, en cuanto a la lucha contra el Estado, el capital, la iglesia y gran parte de sus ideales. Así mismo, se detecta que los movimientos y organizaciones sociales han encontrado puntos de encuentro en su crítica hacia el sistema imperante, herramientas que el anarquismo ha acogido y por ende, ha diversificado. A este respecto, ya no solo lucha contra sus razones clásicas, sino que también su lucha se ha renovado y contextualizado a las demandas de la actualidad, logrando mediatización, debido al carácter protagónico que le atribuyen los medios de comunicación, como autores en las manifestaciones que involucran violencia.

\section{VIOLENCIA POLÍTICA: UNA FÓRMULA QUE HA FUNGIONADO HISTÓRICAMENTE}

En 1968, el destacado filósofo argentino Víctor Massuh iniciaba su libro La libertad y la violencia con esta frase: "La violencia es vieja como el mundo, es la atmósfera en la que invariablemente transcurre la historia de los hombres" (Massuh, 1984, p. 7), y es que para nadie es desconocido que cada acontecimiento histórico ha estado vinculado con la violencia política, en la cual un grupo ejerce la fuerza contra otro con diferentes objetivos. Muchos aplauden la violencia como Nietzsche, denominándola "la moral de los amos", una forma de liberarse y una cualidad del superhombre; Marx como "la partera de la historia" como "principio vital y dinamizador de la historia"; Spengler como "el verdadero antídoto contra la decadencia”, otros no se convencen de su capacidad creadora como Hannah Arendt, quien manifiesta que "la violencia puede destruir al poder; es absolutamente incapaz de crearlo" (Arendt, 2005, pp. 44-56). 
En esa línea, la autora señala una división entre ambos aspectos, mientras John Keane rebate esa idea y declara que si bien "Arendt admite que, en la práctica, violencia y poder se entrecruzan, pero, llevada a su purismo, insiste en la división teoría y en la primacía del segundo sobre la primera, y cae irremediablemente en un pacifismo mal entendido" (Keane, 2000, p. 71). Y es que como menciona John Keane, a veces el resultado de una guerra depende de la duración del conflicto y ferocidad, es decir, dependen de la violencia y está a su vez da poder. Por ello, se establece una relación dialéctica entre violencia y poder. El que logre convocar ambos elementos va a conseguir la hegemonía y podrá disponer a su antojo, que bien puede ser el gobierno de turno o un grupo armado que persiga diversos fines sea revolucionarios u otros.

La violencia política ha estado presente históricamente. Para René Girard "se convierte en fundadora del orden social. Se impone como una necesidad para las sociedades, sean cuales fueren" (Girad, 1980, citado en Crettiez, 2009, p. 33), siendo empleada como un "mecanismo para dirimir conflictos sociales a lo largo del pasado siglo [...] la shoah, la guerra de Corea, las revoluciones mexicana (1910), rusa (1917), china (1948), cubana (1959), nicaragüense (1979), la guerra de Vietnam [...] las dos guerras del Golfo Pérsico" (Beriain, 2004, p. 83). Continúa en un gran etcétera, y es que la violencia funciona para la consecución de ciertos fines. ¿Cómo se logró instalar el sistema capitalista en los países del Cono Sur? Como lo señalan Naomi Klein o Tomas Moulian, por una doctrina del shock, de terror, de miedo en el que la violencia adquiere un papel protagónico y central. Por tanto, destacamos al igual que Hannah Arendt, el "enorme papel que la violencia ha desempeñado siempre en los asuntos humanos" (Arendt, 2005, p. 16). En ese marco, Víctor Massuh, identifica que se ha dado históricamente dos clases de hombres engendradores de violencia: un hombre apocalíptico que se nutre de la violencia y un hombre que elude la violencia (Massuh, 1984). Este autor destaca las cualidades del segundo hombre, que si bien engendra violencia, lo efectúa de forma cauta, y cuestiona a este hombre apocalíptico.

La violencia se ha cimentado en la institucionalidad política, como un medio para solucionar conflictos y tensiones que siempre están latentes de forma implícita o explícita en la sociedad. No solo la ejercen las guerrillas, los grupos anarquistas o rebeldes, sino que también las élites políticas que están cargo del Estado, en los cuales su violencia está legitimada por los dominados, como lo advierte Pierre Bourdieu. Por tanto, los dominadores intentan criminalizar a los actores que se rebelan en contra de ese 
orden que se ha establecido a través de las transacciones entre las élites económicas y políticas. El historiador Rafael Cruz (2008), nos recuerda que, la mayor cantidad de violencia ha provenido desde los gobiernos, sin embargo la que ha sido menor, pero mayormente resaltada es la de los grupos aislados.

Muchos consideran a la violencia como una bestialidad, en particular la que ejercen estos grupos criminalizados como los mapuches, los estudiantes, los encapuchados, y no comprenden que esa expresión "puede representar, pese a quien pese, una protesta moral simbólica contra el mal absoluto y, por tanto, un aviso a las generaciones venideras de que la barbarie no puede tolerarse" (Keane, 2000, p. 68). De modo que, la violencia no es un asunto nuevo por el que la población deba aterrorizarse, sino que históricamente ha estado presente, como un medio para terminar los conflictos y tensiones latentes en la sociedad. Un medio que es ampliamente cuestionado o apoyado por diversos intelectuales, pero que es empleado tanto por las élites que se amparan bajo la legalidad, como también por los movimientos, organizaciones sociales, anarquistas, que se sitúan en la ilegalidad. Ambos sectores, con diversos sentidos que le dan a la violencia política.

\section{VIOLENCIA POLÍTICA: VIOLENCIA DEL ESTADO VERSUS TERRORISMO}

La violencia es una construcción cultural que ha operado en el tiempo a través de los diversos procesos históricos, como una forma de resolver las situaciones en conflicto que se han desatado por diversas razones. Se entenderá a la violencia política como "toda acción no prevista en reglas, realizada por cualquier actor individual o colectivo, dirigida a controlar el funcionamiento del sistema político de una sociedad o a precipitar decisiones dentro de ese sistema" (Aróstegui, 1994, p. 44). La violencia funciona como una herramienta para conseguir objetivos muy diversos en una población que no percibe estos actos o no los quiere percibir, pues se instaura en el sistema social cierto entramado de creencias, o como los denomina Bourdieu "símbolos" que estructuran y cohesionan el sistema simbólico, en el cual la violencia le corresponde a las masas, las que queman buses, generan destrozos, destruyen propiedad privada criminalizando a la población, y lo que efectúa el Estado se esconde bajo el velo de la impunidad, haciéndose llamar fuerza legítima. 
Al respecto, el historiador Julio Aróstegui (1994), nos señala que "no toda violencia tiene la forma pura de agresión, pero sí la de tendencia a la imposición, al dominio de una parte sobre la otra en el conflicto" (p. 40). Para la consecución de fines, que es lo que efectúa esa élite, lo anterior se relaciona también con lo propuesto por Bourdieu, al postular que símbolos como el lenguaje, la religión y los sistemas simbólicos como la escuela y la iglesia, contribuyen a "la dominación de una clase sobre otra (violencia simbólica) aportando el refuerzo de su propia fuerza a las relaciones de fuerza que las fundan, contribuyendo así, según la expresión de Weber a la 'domesticación de los dominados"' (Bourdieu, 1999, p. 69). En esa institucionalidad política, entendida como "un atributo de la vida pública que debe construirse a partir del convencimiento de voluntades particulares y la articulación de los intereses que definen el sentido mismo de la acción colectiva" (Uvalle, 2001, p. 15), y que descansa sus bases en la Constitución, no solo interviene un gobierno, sino que también la nación. Por tanto, es una élite elegida la que detenta la violencia, pero también la población puede empoderarse de esta y ejercerla, lo que se denomina comúnmente como "terrorismo" o "violencia revolucionaria”. El ex-analista de la Secretaría de la Defensa Nacional en Francia y cientista político, JeanMarc Balencie, citado en Bichara (2010) lo define de la siguiente forma:

Una secuencia de actos de violencia, debidamente planificada y altamente mediatizada, que toma deliberadamente como blanco a objetivos no militares a fin de crear un clima de miedo e inseguridad, impresionar a la población e influir en los políticos con la intención de modificar los procesos de decisión (ceder, negociar, pagar, reprimir) y satisfacer unos objetivos (pp. 306-307).

En la línea del autor, el terrorismo buscaría provocar un impacto, instalar un ambiente violento que inste al logro de los fines que ellos persiguen. En tal sentido, la politóloga, Donatella della Porta, se adhiere a esos componentes y hace hincapié en tres elementos que presenta el terrorismo contemporáneo, el primero es el objetivo de la acción el cual es elegido en base a su valor simbólico, el segundo es la acción que pretende generar efectos psicológicos y el tercero es la construcción de mensajes distintos para objetivos diversos. Para la investigadora, su eficacia se asocia a una naturaleza alegórica, mostrando la debilidad de la estructura social (della Porta citada por González-Calleja, 2006). 
Ahora bien, se pueden encontrar dos tipos de terrorismo, el local o regional que se enfoca en "un lugar específico y con un objetivo (enemigo) claramente fijado, de tal forma que sus acciones van dirigidas solo a la población de un espacio geográfico concreto" (Rodríguez, 2012, p. 80); y un terrorismo global o internacional, que abarca a todo el planeta. Ambos tipos difieren en sus objetivos, el terrorismo local o regional, en el cual se encuentra el terrorismo nacional puede tener objetivos negociables, mientras que en el terrorismo internacional, solo será satisfecho con repercusiones globales. Si bien en el caso del terrorismo regional su organización es más pequeña, no significa que sea menos compleja; y en el internacional, posee ramificaciones o franquicias. Las dos estrategias son distintas, depende del tipo de personas al que se van a dirigir, si son públicos específicos o generales. También, se puede clasificar el terrorismo, según su origen, función, efectos y naturaleza.

El terrorismo local o regional, ha sido asociado al "terrorismo urbano", que se da en las ciudades y puede "utilizar métodos terroristas, pero su intención es precisamente crear espacios de disidencia política cada vez más amplios, en una estrategia insurreccional global de guerra civil" (González-Calleja, 2006, p. 490). Por tanto, el terrorismo urbano, se posiciona como una forma de concretar la violencia política con un sentido de rebelión ante el orden establecido, subyace que son los otros que generan estas conductas terroristas y no el Estado. En relación a ello, el académico de la Universidad de Hull en Reino Unido, Noel O’Sullivan, nos manifiesta que el terrorismo aparece cuando un grupo que detenta el Poder Gubernamental o está fuera del gobierno, resuelve alcanzar un conjunto de objetivos ideológicos por métodos que violan o ignoran las estipulaciones del derecho nacional e internacional, esperando tener éxito principalmente por la amenaza o uso de la violencia. En ese orden de ideas, el tan "manoseado" terrorismo no se remontaría solamente a las acciones que impliquen el uso de la violencia por parte de grupos anarquistas o asistémicos, sino que es un "arma específica en la lucha por el poder político, empleado por grupos de la extrema izquierda o de la extrema derecha, pero también, muy frecuentemente por minorías nacionales" (O’Sullivan, 1987, p. 21). La violencia se constituye así como el fondo de las acciones humanas.

Por otro lado, el destacado sociólogo, Johan Galtung, afirma que la violencia se puede dividir en tres acciones: 
La violencia directa, física y/o verbal, es visible en forma de conductas. Pero la acción humana no nace de la nada, tiene raíces. Se indican dos: una cultura de violencia (heroica, patriótica, patriarcal, etc.) y una estructura que en sí misma es violenta por ser demasiado represiva, explotadora o alienadora; demasiado dura o demasiado laxa para el bienestar de la gente (1998, p. 15).

De acuerdo a lo anterior, la violencia cultural y violencia estructural, son las raíces que causan las violencias directas, "utilizando como instrumentos actores violentos que se rebelan contra las estructuras y empleando la cultura para legitimar su uso de la violencia” (Galtung, 1998, p. 15). Siguiendo la teoría de Johan Galton, considera que:

La violencia estructural (o injusticia social), de venida de las condiciones materiales e institucionales en que se desenvuelve la vida de los sujetos [...] y la violencia reactiva, protagonizada por los explotados, excluidos y reprimidos, que constituye una respuesta inducida por la violencia anterior (Galtung, citado en Goicovic, 2013, p. 11).

Es así como se puede diferenciar una violencia estructural inserta en el sistema político, económico y social, que es la violencia que legítima el Estado, y una violencia reactiva que es desarrollada por estos grupos que se les denomina "terroristas". Estos grupos terroristas "justifican su existencia echando en parte mano a la vieja tradición marxista-leninista de la vaciedad e inutilidad de los procedimientos democráticos y asegurando, por otro lado, su carácter esencialmente fascista" (García, 1897, p. 67). No conciben una democracia como la actual, la ven como un títere de las élites.

En la violencia se da una relación dialéctica en la que intervienen ciertas condiciones, las cuales se desglosan primero como los conflictos y contradicciones que afectan a la sociedad; segundo el comportamiento violento devenido en daño sobre los otros; y tercero, las legitimaciones culturales o ideológicas de las violencias estructurales y directas (Tortosa, 2002, citado en Goicovic, 2013). Por ende, independientemente de los calificativos que se empleen para referirse a ella, la violencia es útil para solucionar de forma drástica los conflictos, y este terror que se esparce por medio de la violencia permite mantener un control social, específicamente psicológico. Ese terror es de utilidad a los diferentes actores que emplean la violencia, no solo por parte de los sujetos denominados terroristas, sino que como bien señala Zeev Ivianski, "el terrorismo revolucionario prepara 
el camino para otro mucho más poderoso: el contraterrorismo del Estado totalitario" (Ivianski, citado en Rapoport, 1985, p. 59), siendo esta última la respuesta.

De modo tal se entenderá que el Estado considera al "terrorista" como un elemento disruptivo en la sociedad "al resquebrajar el contrato social, el terrorismo desestabiliza el orden moral, ideológico, legal y simbólico, mientras que el Estado monopoliza para sí el uso legítimo de la violencia” (Carrié de la Puente, 2011). La violencia revolucionaria, desatada por estos grupos denominados "terroristas", es considerada una violencia reactiva ante la violencia estructural del sistema impuesto, lo que evidencia un conflicto en la sociedad, que se materializa en un comportamiento violento, en el cual se generaran daños hacia ese otro, bajo el velo de la legitimización cultural de la violencia estructural y directa. Se espera que el Estado controle con el uso de la fuerza esas manifestaciones violentas que "serían propias" de esos grupos terroristas, que desarrollan sus acciones tanto a nivel local en la forma de terrorismo urbano, como internacional con distintos orígenes, funciones, naturaleza y efectos.

\section{LA VIOLENCIA EN EL ANARQUISMO: EL MEDIO PARA LA REVOLUCIÓN}

Se suele asociar con terroristas a los grupos anarquistas y es que precisamente el discurso ideológico de fondo hace referencia a la violencia, una violencia que transgrede y amenaza al aparato estatal y sus tres poderes: moral, económico y político, ya que el objetivo es derrumbar ese orden de concentración de poder. En ese orden de ideas, uno de los máximos exponentes del anarquismo, Mijaíl Kropotkin, indica que "el hombre valeroso prefiere morir antes de llegar a ser la causa del mal de otros. Por esto tendrá conciencia de proceder bien y la aprobación de los que estima lo seguirá si mata a la víbora o al tirano” (Kropotkin, 2008, p. 36). La instauración de esta sociedad libertaria, solidaridad, igualitaria y equitativa, requiere de una transformación que implica un proceso transgresor, subversivo, un proceso revolucionario de cambio en su extensión. La violencia, se constituye como un recurso que permite asegurar la revolución y acabar definitivamente con la raíz del problema, que para los anarquistas es el Estado como un medio de concentración de poderes y servidumbre. 
El anarquismo postula que la rebelión debe ser victoriosa, dilapidando las esferas de poder para garantizar una emancipación eficaz y que el pueblo quede libre de configurar las instituciones que cree mejores (Malatesta, 1975, p. 237). De modo que, los anarquistas abrazan la máxima que postula Víctor Massuh, parafraseando a Marx, en la cual la magnitud de la violencia asegura la profundidad del cambio, es liberadora ya que rehumaniza y crea un nuevo orden (Massuh, 1984, p. 15), que es lo que se pretende en la ideología anarquista.

El anarquismo en su vinculación con la violencia ha adquirido ciertos rasgos, a nivel internacional que "fueron de dos tipos: la huelga insurreccional y el terrorismo individual” (Goicovic, 2013, p. 43), otra de sus características que se da en el plano nacional "es el atentado individual o colectivo contra representantes del sistema de dominación. En este caso, el puñal, el revólver y, más tarde, la dinamita, se constituyeron en los recursos materiales más frecuentes en manos de los anarquistas" (Goicovic, 2013, p. 43). Estas manifestaciones de la violencia revolucionaria, consideradas como acción directa, son calificadas terroristas, estableciéndose una relación entre anarquismo y terrorismo, como lo señala la investigadora Perla Jaimes Navarro, asocia "su total aversión a toda forma de gobierno o autoridad, misma que privilegia la soberanía sobre cualquier otra, su antiautoritarismo los ha llevado en ocasiones a cometer atentados contra figuras relevantes" (Jaimes, 2012, s.p.). La violencia se utiliza como una herramienta revolucionaria, en la que algunos de sus usos "contra la violencia que ejercen los opresores y dominadores, considerando que en este caso la violencia es defensiva y no opresora" (Vallota, 2007, p. 42).

Dicho lo anterior, hay un discurso anarquista en que se concibe a la violencia como una herramienta, que permitirá introducir cambios en la sociedad, garantizando la revolución, terminando con las cúpulas de poder, ese discurso incrimina al anarquismo en las diversas manifestaciones violentas. En tal sentido, el discurso se sitúa para ser manipulado y atribuir conductas terroristas a los grupos anarquistas.

La definición de anarquismo que se toma en esta investigación se vincula con lo propuesto por Pamela Quiroga, la cual señala que en Chile se ha vivido un proceso denominado de "politización", abriéndose a espacios de movilización y cuestionamiento a elementos estructurales del sistema neoliberal. Así mismo, el anarquismo en Chile se ha imbricado con organizaciones y movimientos sociales, desarrollando una crítica al capitalismo no solo en su dimensión clásica, sino abarcando otros 
ámbitos como lo cotidiano, la sexualidad, la salud, entre otros, lo que lo sitúa en tensión con el sistema que "se viene abajo en situaciones de crisis, cuando la furia popular desborda sus canales normales y amenaza esos mismos parámetros en cuyo marco opera la práctica política habitual” (Scott, 2013, p. 47). El anarquismo ha cobrado relevancia, vinculándose con otros movimientos sociales, y en los últimos años, se han realizado "menciones a los anarquistas, vinculados principalmente a la figura de los 'encapuchados' y a la violencia en manifestaciones públicas” (Quiroga, 2013, p. 105).

En cuanto al concepto de terrorismo, se entiende según la teoría de Johan Galtung, al considerar que la violencia no proviene solo de estos grupos denominados terroristas, sino que la divide en dos grandes campos de actores, por una parte está la violencia estructural que comprende la injusticia social, resultado de las condiciones materiales e institucionales en que se despliega la vida de los sujetos, sea explotación económica, marginalidad social y étnica, represión institucional, “y la violencia reactiva, protagonizada por los explotados, excluidos y reprimidos, que constituye una respuesta inducida por la violencia anterior" (Galtung, citado en Goicovic, 2013, p. 11). De este modo podemos diferenciar una violencia estructural inserta en el sistema institucional, que es la violencia que legitima el Estado, y una violencia reactiva que es desarrollada por estos grupos que se les denomina terroristas, visto "el terrorismo como una forma extrema del derecho de resistencia” (García, 1897, p. 67).

Una resistencia que se ubica entre un punto intermedio de la legalidad y la revolución, ya que estos grupos terroristas “justifican su existencia echando en parte mano a la vieja tradición marxista-leninista de la vaciedad e inutilidad de los procedimientos democráticos y asegurando, por otro lado, su carácter esencialmente fascista” (García, 1897, p. 67).

La violencia política se ha cimentado en la institucionalidad, como un medio para solucionar conflictos latentes en la sociedad. No solo la ejercen las guerrillas, anarquistas o rebeldes, sino que también las élites políticas que están cargo del Estado, una violencia simbólica que está legitimada por los dominados como lo señala Pierre Bourdieu, y afirma Braud "las organizaciones que recurren a la violencia se sitúan en la ilegalidad" (2006, pp. 53-89), no así el Estado.

Por ende, esta investigación corresponde a la disciplina historiográfica de la historia del tiempo presente, y aborda un fenómeno social, en el cual está de manifiesto una realidad intersubjetiva, que son las comprensiones sobre el anarquismo y terrorismo en relación al "Caso 
Bombas”. En esa línea, este estudio será de tipo cualitativo y adoptará el enfoque del Análisis Crítico del Discurso, propuesto por Norman Fairclough, que interpreta al discurso como una forma de práctica social, lo cual "sugiere una relación dialéctica entre un suceso discursivo particular y las situaciones, instituciones y estructuras sociales que lo enmarcan [...] es bidireccional, el suceso discursivo está moldeado por las situaciones, instituciones y estructuras sociales, pero a la vez les da forma" (Fairclough \& Wodak, citado en Teun van Dijk, 2000, p. 367.). Lo anterior permitirá comprender la dinámica entre prensa escrita y declaraciones políticas, estableciendo las líneas argumentales. Para este fin, se recurre a documentos de acceso público para leer la prensa escrita La Segunda, El Ciudadano y las secciones ordinarias y extraordinarias del poder legislativo chileno, de las cuales se extraerán declaraciones de los parlamentarios y del Ministro del Interior.

\section{EL IMAGINARIO ANARQUISTA}

El 10 de agosto del 2010 en el marco de la denominada "Operación Salamandra”, estalló mediáticamente el Caso Bombas, un hecho cubierto con ahínco por los diversos medios de comunicación en que se apuntaba a los anarquistas. Motivo por el cual los medios de prensa escrita no se excluyeron de escribir sobre el acontecer noticioso, sino que difundieron cada día información sobre esta temática, crearon un "imaginario anarquista”. Entendido como un "conjunto de imágenes mentales. La palabra ‘imagen' nos hace pensar en una idea [...] que no llega a un alto nivel de racionalización [...] puede ser muy convincente en el universo mental de un individuo o de un grupo" (Escobar, 2000, p. 115), un imaginario que se basaba en el desconocimiento sobre el anarquismo chileno, originado en las acusaciones de la Fiscalía Metropolitana Sur. En ese sentido, era importante conocer quiénes eran estos sujetos acusados de ", que creen en la libertad como un principio fundamental de la vida asociación ilícita terrorista”, por lo que lentamente se fue construyendo un sujeto anarquista del cual mucho se dijo, pero ¿Qué es el anarquismo? Si nos remontamos a las bases elementales, son grupos de personas y organizaciones que otorgan valor a la participación y el protagonismo de los implicados, evitándose la dirección del movimiento por unas minorías, su forma organizativa es asamblearia y autogestionaria, se consideran sujetos activos de la historia, que creen en la libertad como un principio 
fundamental de la vida. La construcción del imaginario anarquista que generó el diario La Segunda, se enfocó a dos representantes de la ideología que se tomaron la escena pública durante los más de dos años que duró la resolución del caso. Un primer actor fueron los sujetos directamente acusados en el Caso Bombas y otro, el movimiento anarquista.

En cuanto a los acusados del Caso Bombas, la fiscalía los caracterizó como una organización con "ausencia de esquema organizado de dependencia y funciones de determinados líderes, modo de vida libre, propio de los okupas de otros países". Se comparan sus actitudes "violentas" con la de otros grupos considerados "terroristas" como los de la Fuerzas Armadas Revolucionarias de Colombia (FARC) y los grupos activistas mapuches chilenos (La Segunda, 16 de septiembre del 2010, p. 8). Ahora bien, la noticia titulada "Caso Bombas: Recrean cómo desde la Cárcel de Alta Seguridad surgen nexos de anarquistas y exsubversivos" (La Segunda, 13 de junio del 2011), se exponen los principales elementos de un informe pericial, en el que se establecería el nexo entre anarquistas y exsubversivos, señalándose que la historia se inicia en la Cárcel de Alta Seguridad, cuando desde mediados de los 90 e inicios de los 2000, fueron encarcelados sujetos de agrupaciones subversivas, que durante los gobiernos de la concertación, realizaron acciones de reivindicación política, sea asesinato, expropiación o sabotaje. Según eso, en la Cárcel de Alta Seguridad (CAS) habría nacido el movimiento anarquista Kamina Libre, cuyo objetivo sería potenciar la difusión y el trabajo por la libertad de todos los presos políticos, incluyendo a los mapuches, ambos habrían optado por modalidades operativas disimiles y buscarían generar impacto en la opinión pública. Así mismo, se destaca que los autores de los atentados pertenecen a la mayor red de apoyo anarquista y que tienen afinidad con el ecologismo, con grupos musicales de punk y hardcore. A su vez, habría vínculos con los atentados internacionales como bombas en embajadas, constituyéndose en una gran red de apoyo, atribuyéndole un carácter transnacional al anarquismo (La Segunda, 18 de enero del 2012).

En la formalización de los imputados, La Segunda destaca la acusación del Fiscal, Alejandro Peña, en la que estas personas buscarían infundir temor (La Segunda, 28 de mayo del 2012). También, se hace énfasis visual con letra negrilla, que según el Fiscal Peña, buscarían provocar una guerra social. Se manifiesta que tienen "centros de poder", que serían las casas okupas y sus líderes informales serían Rodolfo Retamales y Pablo Morales (La Segunda, 17 de agosto del 2010), lo cual es un contrasentido, pues los anarquistas no tienen liderazgo, haciéndose eco de esa aseveración 
de la fiscalía. A su vez, según las declaraciones del testigo protegido, los acusados tendrían apodos tales como "punki Mauri", "El Garza” y el "Cariñosito".

El diario La Segunda hace énfasis en la cantidad de años de presidio que se solicita a los 14 acusados, así como en la gravedad de la acusación: "asociación ilícita, financiamiento, colocación de artefacto explosivo hasta porte y tenencia de arma de fuego" (La Segunda, 4 de abril del 2011, p. 7). Se difunde lo peligrosos que son estos sujetos para la sociedad chilena, no son cualquier tipo de terroristas, se justifica que deban estar en la cárcel.

En cuanto al movimiento anarquista, en el mes de octubre el periódico hacía mención en que "Furiosos asistentes a tocata por detenidos del Caso Bombas dejan 4 carabineros heridos", noticia en la cual se deja claro que asistió gente anarquista al Galpón Víctor Jara en Plaza Brasil y en la que era inevitable que el ambiente se pusiera "caliente" (La Segunda, 25 de octubre del 2010). Se les atribuyen conductas de gente turbulenta que genera disturbios, golpea a fuerzas de orden y realiza destrozos a la propiedad privada. Además, se denomina como "batalla campal” la lucha entre carabineros y anarquistas, configurando así a los manifestantes como una masa enfurecida, con actitudes impulsivas.

El movimiento anarquista desarrolla diversas acciones relevadas por La Segunda, como "Reaparecen los bombazos después de tres meses: sospechan de anarquistas", noticia en que se destacan las declaraciones del Fiscal Peña, en la cual señalaba que "es muy probable que en las próximas horas grupos antisistémicos se adjudiquen estos nuevos atentados" (La Segunda, 20 de diciembre del 2010, p. 2). A la vez, se vincula el hecho con los detenidos del Caso Bombas, en el que cabe citar las preguntas intencionadas del periodista al fiscal, “¿Corresponde a los mismos patrones anarquistas por los cuales formalizó a 14 personas en agosto?”. Al igual, con letra negrilla el diario señala "tampoco se encontraron rayados o panfletos" (La Segunda, 20 de diciembre del 2010, p. 2), asociándose esa acción como algo típico de estos grupos. Destacan las afirmaciones y preguntas del tipo “iAntes era odiado por los narcos, ahora es odiado por los anarcos...! ¿Qué piensa usted del anarquismo como corriente ideológica?” (La Segunda, 20 de agosto del 2010, pp. 18-19). La atención la enfocan a priori en los anarquistas, y son insistentes en encauzar las preguntas hacia ellos, subyace un discurso que asocia a estos individuos con delincuentes comparables a los narcotraficantes.

En paralelo, se da una "ola de atentados" en la Región Metropolitana, que el diario cubre elocuentemente, ocurren sucesos como una bomba 
en un cajero automático en la comuna de Vitacura, en que se manifiesta que "el lugar tenía panfletos anarquistas que respaldaban a los "presos políticos' del llamado Caso Bombas" (La Segunda, 11 de agosto del 2011, p. 39), además se caracteriza al sospechoso, que pudo haber sido un hombre delgado y alto, vestido de negro con capucha, del cual no se identifica su cara y que dejó la caja a medianoche. A la vez, se da cobertura a otro hecho, una bomba que estalla en la madrugada en un edificio del Ministerio Público, la que estaría asociada con anarquistas (La Segunda, 29 de noviembre del 2011). Asimismo, el atentado explosivo a una sucursal del Banco Estado, en el que los sujetos usan gorros y guantes quirúrgicos, pero que no hay adjudicados (La Segunda, 6 de marzo del 2012).

Por otra parte, destaca la noticia en la cual se caracteriza a individuos, que si bien no colaboran con los acusados del Caso Bombas, sí representarían la ideología, como la siguiente titulada, "Anarquistas amedrentan a profesor de la 'U' y se vanaglorian de quemar bus del Transantiago" (La Segunda, 25 de octubre del 2012, p. 2), en la que se señala que son grupos violentos, junto con haber tenido una actitud violenta hacia los pasajeros.

La Segunda, desarrolla una hipótesis a partir de datos de carabineros, sobre una clasificación del movimiento anarquista expuesta en la noticia titulada "Perfil de violentos enrabiados que toman protagonismo en la movilización" y en la que aparece una imagen de encapuchados con perros. Se animaliza su accionar, señalándolos como individuos "más rabiosos que perros", de corte anarquista y de izquierda, que se los puede clasificar: "los antiguos [...] ligados a grupos antisistémicos que surgen durante los 80, los ideológicos [...] ligados a movimientos indigenistas y ecológicos", los de "moda [...] que tienen antecedentes penales por robo y desórdenes [...] los motiva la violencia desmedida" (La Segunda, 21 de octubre del 2011, p. 10). En la noticia se cuestiona que tipo de manifestantes son “¿Ultra malos, ultra politizados o ultra qué?".

A nivel internacional, también se desarrollan una serie de atentados, dos de ellos en la embajada chilena ubicada en Grecia en la que se intercepta una bomba que estaría vinculada a una serie de sucesos en Europa, dicha acción fue atribuida a grupos de izquierda "específicamente la organización anarquista 'Conspiración de núcleos de fuego" (La Segunda, 2 de noviembre del 2010, p. 2). Así la información, los anarquistas constituirían una nueva amenaza terrorista que sería analizada por la Unión Europea. Meses después, "Anarquistas se toman durante una hora embajada chilena en Grecia" (La Segunda, 28 de marzo 
del 2011, p. 17), en apoyo a los detenidos que están en huelga de hambre, los cuales estuvieron cerca de una hora y dejaron panfletos y enviaron fax al Ministerio de Justicia y Cancillería chilena. En otros países, como el caso de la embajada chilena en Roma, en la que explotó una bomba dejando a un funcionario herido, noticia que con frase en negrilla hacía hincapié en que "se sospecha de ecologistas anarquistas" (La Segunda, 23 de diciembre del 2010, p. 2). También un atentado en Barcelona (La Segunda, 2011, 28 de abril), y en EE. Uu., noticia en que se señala que las redes internacionales anarquistas reactivaron sus acciones en apoyo a los 14 acusados del Caso Bombas (La Segunda, 25 de abril del 2011). Con lo anterior se evidencia la intención por tornar una situación violenta puntual como lo es un artefacto explosivo, en un fenómeno "terrorista" de carácter internacional.

El diario destaca la forma de expresión y reivindicación de las acciones en un sitio web denominado "Homodolar.org", que se constituye como el diario mural de los anarquistas, "donde se mezclan informaciones sobre el conflicto mapuche, los presos políticos de Europa y Latinoamérica, reivindicaciones de atentados y hasta manuales para hacer bombas y armas hechizas", pero habría otros sitios denominados "la contrainformación", que serían redes infinitas, en las que "se entrecruzan con historias personales de características patológicas que se develan en imágenes y escritos por internet [...] voces salidas desde la angustia existencial, rayando en la paranoia [...] vomitando desde el estómago en contra del mundo" (La Segunda, 20 de agosto del 2010, p. 22). Para el diario, la culpa de sentirse marginados se la adjudican al capitalismo y caracteriza su actitud como la de gente enferma, paranoica e irracional, por lo que se sugiere que no hay que comprenderlos, ya que son dementes.

Si el diario La Segunda fue una reproducción de las pruebas de la fiscalía y algunos planteamientos creativos en contra de los acusados, el diario El Ciudadano, desde el primer momento consideró que esto era un montaje en contra de los anarquistas. Para ellos, los anarquistas han actuado generando espacios de discusión y pensamiento, recuperando lugares abandonados (casas okupas) (El Ciudadano, octubre del 2010), dando espacio a columnas de opinión como la de un militante de la Federación de Estudiantes Libertarios (El Ciudadano, junio del 2012), como también con titulares de este tipo "Anarquistas del mundo se reunieron en Suiza", noticia en la cual se difunde sobre la reunión mundial del anarquismo en la ciudad de Saint-Immier (El Ciudadano, agosto del 2012) y se da espacio a la disidencia. Los periodistas de este 
diario, consideran que la autoridad persigue a la resistencia política como los acusados del Caso Bombas "por estar acusadas de ser violentistas y mostrarse en contra del sistema, ven disminuidos sus derechos ante la justicia” (El Ciudadano, octubre del 2010, p. 11). El diario considera que los anarquistas, "son exhibidos por el poder para decirnos que cualquiera puede ser acusado, encerrado, asesinado y nadie dirá nada” (El Ciudadano, abril del 2011, p. 6). Mientras te mantengas en el sistema, no te constituyes en enemigo de la nación.

El Ciudadano realiza una crítica hacia lo que ellos denominan "El show de las bombas", señalando irónicamente que anarquistas, antiautoritarios y exmilitantes del Mapu-Lautaro, son terroristas con domicilio conocido, que entran y salen de casas okupas, los que serían sus centros de poder y que su financiamiento exterior sería solo 700.000 pesos (El Ciudadano, septiembre del 2010). Sitúan en tela de juicio la acusación hacia los anarquistas, que según la Fiscalía Metropolitana Sur, tendrían un liderazgo informal (El Ciudadano, agosto del 2010). Una construcción del sujeto anarquista dispar al diario La Segunda, no se avala en la versión oficial, sino que posibilita la reflexión sobre las intenciones detrás de esta “creación anarquista”, alejada de la realidad por ser sumamente superficial.

En cuanto a la caracterización que realiza el Poder Ejecutivo y Legislativo sobre los imputados supuestamente anarquistas, se puede dividir en dos momentos. Un primer momento en donde se condena sin el veredicto de los jueces y una segunda instancia en la que se demuestra que los acusados son inocentes de los cargos de "asociación ilícita terrorista”. Uno de los primeros pronunciamientos al respecto viene de parte del Senador de Renovación Nacional, José García Ruminot, el cual manifestó una actitud de condena hacia estas personas que colocaron más de 100 artefactos explosivos en la Región Metropolitana. Para el Senador, "los ciudadanos honestos de nuestro país tienen derecho a que una bomba no les perturbe su descanso en la noche o su trabajo al mediodía [...] no se vea interrumpido por la detonación de un artefacto explosivo" (Diario de Sesiones del Senado, 2010, p. 4666). Los sujetos acusados del Caso Bombas, son vistos como personas violentas y culpables de generar temor en la población, elementos disruptivos, expresiones que no poseen un fundamento que las avale legalmente. Por su parte, el Ministro del Interior, Rodrigo Hinzpeter Kirberg, manifestó su reprobación en relación al vínculo entre una exjefa de Seguridad Ciudadana de la Intendencia Metropolitana con Rodolfo Retamales, "si hubo personas que trabajan en seguridad ciudadana dentro del Gobierno anterior y 
tuvieron relaciones o ayudaron a quienes hoy día aparecen formalizados, es un tema muy grave que va a tener que ser investigado en este proceso" (La Segunda, 18 de agosto del 2010, p. 6). Una actitud de condena, que pone en evidencia en reiteradas ocasiones. En relación a bombazos que se produjeron con posterioridad a la detención de los 14, el ministro expresó la necesidad de esclarecer si se trata de procedimientos y grupos nuevos o ya conocidos (La Segunda, 20 de diciembre del 2010). Según el ministro, hay personas que se sienten con la facultad para adquirir, elaborar, transportar y colocar artefactos explosivos "cuya capacidad de causar muertes o severas lesiones y mutilaciones está más que acreditada” (Cámara de Diputados, 2012, p. 363).

Ahora bien, al declarar inocentes a los acusados del Caso Bombas, la actitud hacia ellos cambia rotundamente, de hecho las palabras de Hinzpeter dan cuenta de ello "ya en 2008 había cuatro organizaciones identificadas como responsables de los bombazos [...] Aquellos que terminan con absolución muchas veces no son un fracaso, al contrario, son un acierto que permite hacer claridad respecto de la no responsabilidad de determinados ciudadanos" (Cámara de Diputados, 2012, p. 363). Da cuenta que debe ser visto como un descarte de posibles terroristas. Mientras que por su parte, la Comisión de Investigación sobre el Caso Bombas de la Cámara de Diputados, manifestó que durante los nueve meses que los acusados estuvieron detenidos en la cAs, se hallaron 18 artefactos explosivos, para un promedio anual de 20. Para la Cámara de Diputados, esto constituyó una situación de gravedad en dos aspectos, el primero de ellos que se privó de la libertad a 14 personas que eran inocentes y el segundo, porque aún no hay culpables de los bombazos, evidenciando así la incapacidad de la Seguridad Pública y de los que están cargo de la persecución penal en Chile (Cámara de Diputados, 2012).

Para Jesús Martín Barbero, “comunicar es compartir la significación” (2002, p. 1), y en línea con ese pensamiento tanto La Segunda como El Ciudadano, y los representantes de la Cámara de Diputados, Senadores y Ministro del Interior, se hacen partícipes y difunden a la población la percepción que ellos poseen sobre los anarquistas, que se diferencian significativamente. El diario La Segunda, basó su forma de comunicar avalándose en antecedentes que le otorga la fiscalía, en una versión "oficial del caso", la cual aprehende como punto de partida para generar sus propios planteamientos. A partir de ahí ellos interpretan, como la noticia con el titular "Perfil de violentos enrabiados que toman protagonismo en la movilización”, en la cual generan una clasificación de los sujetos 
antisistémicos. En cuanto al diario El Ciudadano, no adopta la versión oficial, sino que más bien la crítica y da espacio a planteamientos independientes. Algunos de los representantes del Poder Ejecutivo y Legislativo que revisamos, manifiestan una actitud de condena en una primera instancia, para luego, cuando los sujetos son declarados inocentes situar el énfasis en que aún no hay responsables de los bombazos, la atención en la impunidad reinante en el país.

Por tanto, el diario La Segunda construyó a un anarquista identificándolo como un delincuente de alta peligrosidad, el cual actúa bajo las sombras, con una actitud irracional e impulsiva, que emplea pretextos políticos para justificar su accionar al atentar contra el Estado y la propiedad privada, generando miedo en la población nacional e internacional, al dejar panfletos y rayados en sus acciones, las cuales son reivindicadas por medio de páginas de internet en las cuales "vomitan" su sentimiento de marginalidad. Los anarquistas se constituirían como una rotura en el tejido social, una epidemia que es capaz de motivar a la población a imitar sus acciones delictuales. El origen de los acusados del Caso Bombas, se basó en la Cárcel de Alta Seguridad, en la que exlautaristas y subversivos se organizaron y conformaron la agrupación para el excarcelamiento de presos políticos, Kamina Libre. Este movimiento, como lo plantea Pedro Rosas, fue de resistencia de los presos políticos a los cuales se "satanizó y criminalizó hasta el paroxismo la actividad política rebelde sobre la base de una estrategia de gobernabilidad y redisciplinación postautoritaria” (Rosas, 2004, p. 300). En la línea de La Segunda, se deshecha esa idea de criminalización, y la cas se constituye en el lugar donde se originaria la "semilla del mal", de la cual surgen los anarquistas.

El Ciudadano tampoco avala la versión oficial de la fiscalía, puesto que concibe a los anarquistas como sujetos de resistencia política, víctimas de un estigma negativo, parte de la disidencia que es oprimida, pues no comparten la concepción en la que el sistema neoliberal con las desigualdades sociales priman.

Es así que los medios de prensa escrita, ejercieron un control estratégico del conocimiento, "mediante una restringida selección de temas y, de modo más general, mediante reconstrucciones específicas de las realidades sociales y políticas" (Van Dijk, 2009, p. 70), con el fin de incidir sobre los modelos mentales de las personas. Una actitud en la que se manipulan las creencias sociales. 
Los representantes del Poder Ejecutivo y Legislativo condenaron a estos sujetos sin fundamentos de peso, basta recordar que la acusación de la fiscalía, se basaba en deficientes pruebas como "gran cantidad y variedad de libros, afiches diferentes y documentación incautados el 25.08.10" (Fiscalía Metropolitana Sur, 2010). Posterior a la declaración de absolución de cargos a los imputados, la atención no se centró prioritariamente en ellos, sino en que aún esos sujetos que ponen bombas andan sueltos, el enemigo de esa supuesta paz y estabilidad de la democracia anda al acecho.

Los imaginarios anarquistas de los periódicos y del Poder Ejecutivo y Legislativo, corresponden a contextos simbólicos que permiten "expresar el saber social que se encuentra en la base fundacional de lo social [...] devienen como sugestiones o ilusiones que 'encantan' a los individuos dándoles las seguridades simbólicas necesarias para enfrentar su devenir histórico o las contingencias de la existencia” (Martínez \& Muñoz, 2009, p. 212). En el caso del diario La Segunda, al representar a los anarquistas como delincuentes peligrosos y en el caso de El Ciudadano, al no cobijarse bajo el alero de lo oficial y al percibir a este sujeto anarquista como parte de la disidencia. A su vez, El Poder Ejecutivo y Legislativo al nominarlos como culpables y luego ignorarlos, se convierten en formas de concebir y comprender la realidad, significarlas, les otorga una cierta concreción a sus creencias de lo social. Así mismo, establecen control social a través de su posición de poder, el cual es ejercido sobre el discurso que producen, controlando las opiniones, representaciones personales y sociales del mundo.

\section{ANARQUISMO Y TERRORISMO}

En paralelo a la acusación del Caso Bombas, se realizó tanto en las sesiones del Senado como en la Cámara de Diputados, un debate en torno a la legislación antiterrorista, ya que el Poder Ejecutivo envió un proyecto de ley, sobre el cual el parlamento se pronunció de forma diversa en el contexto del conflicto del Movimiento Mapuche en la Araucanía, con la huelga de hambre que efectuaban activistas mapuches y en Santiago, con el Caso Bombas. En relación a este último, podemos denotar la actitud en la que según el diario El Ciudadano, "el Ministerio del Interior presionó al Consejo de Defensa del Estado, para que presentara la querella por Ley Antiterrorista en contra de los formalizados" (El Ciudadano, 2010, 
septiembre, p. 7). La actitud condenatoria de Hinzpeter, no solo fue hacia los anarquistas, sino que "su prioridad era la seguridad pública y el combate a los terroristas y subversivos" (El Ciudadano, noviembre del 2010 , p. 10). Es decir, atacar la disidencia política, que fue lo que intentó también hacer mediante la famosa Ley Hinzpeter, en la que se aumentan las sanciones a los que oculten su identidad mediante capuchas u otros medios (Cámara de Diputados, 2011) en las movilizaciones sociales. Ambas leyes, criminalizan a la disidencia política que utiliza la violencia para manifestarse en contra del orden político.

Para entender la vinculación que efectuaron entre anarquismo y terrorismo, debemos tener presente que en ambas Cámaras, la de Diputados y Senadores, se discutió en torno a lo que se entiende por terrorismo. El 9 de septiembre del 2010, el Poder Ejecutivo envió un proyecto que modifica la Ley $n .{ }^{\circ} 18.314$, que determina conductas terroristas y fija penalidad, en la que el Presidente de la República, Sebastián Piñera, manifestó que "los actos terroristas no sólo ponen en peligro la seguridad e integridad de las personas, sino que además socavan las instituciones democráticas y sociales" (Presidencia de la República, 2011). Para la senadora democratacristiana, Soledad Alvear, dicho proyecto cambia el concepto de conducta terrorista, al asociar los hechos delictivos destinados a extraer "resoluciones de la autoridad o a imponerle exigencias con la finalidad de producir temor en la población o en una parte de ella [...] suprime la presunción [...] da por supuesta la finalidad de producir temor" (Sesiones del Senado, 2010,14 de septiembre, p. 4639). De este modo se genera una discusión en torno a las ambigüedades que presenta el proyecto de ley, el cual da lugar a múltiples interpretaciones, y las que se desprenden de las declaraciones del ministro Hinzpeter, "el colocar o lanzar bombas o incendiar un bus [...] pueden o no ser calificadas como terroristas. A la inversa, si se ejecutan para causar desestabilización o pánico social - conceptos del artículo $1^{\circ}$ - y no como mero vandalismo, serán conductas terroristas" (Diario de Sesiones del Senado, 2010, 15 de septiembre, p. 4840). Sin embargo, ¿qué se entiende como pánico social? ¿Desestabilización? Porque en el artículo al cual hace referencia el ministro, se habla del temor como elemento eje, pero ¿cómo se mide el temor? En relación a ello, el senador democratacristiano, Jaime Quintana señala que "si amenazo [...] con que mañana voy a poner una bomba en el Metro, provocaré obviamente una conmoción social (Sesiones del Senado, 2010, 15 de septiembre, p. 4887)”. Dependería de la intención, pero, ¿cómo se distingue eso? Es decir, la ley no está libre de ambigüedades. 
En relación al Caso Bombas, el senador de Renovación Nacional, José García, señaló "que quienes hoy se hallan procesados por colocar bombas o explosivos en la Región Metropolitana y que están siendo investigados por delitos terroristas lo hacían 'para entretenerse' [...], lo hacen para perturbar el normal desarrollo de las actividades" (Diario de Sesiones del Senado, 2010, 15 de septiembre, p. 4850). Como se puede observar, son aseveraciones subjetivas que dan por supuesto que los acusados cometieron actos de terrorismo con el objetivo de alarmar a la sociedad.

La Cámara de Diputados no estuvo exenta de discusiones en torno a este proyecto en un contexto de conflictos a nivel nacional. Se presentaron mociones para "restringir la calificación como terrorista sólo a los ataques más graves, a bienes jurídicos de la mayor importancia, referidos al ámbito de la indemnidad personal de los individuos [...]. Se excluye, por ende, la propiedad" (Cámara de Diputados, 2010), y también una moción en la que se pretendía eliminar a los testigos sin rostros, ya que, a su juicio desnaturalizan la esencia de la prueba testimonial los que en el Caso Bombas, tuvieron un papel trascendental para avalar las acusaciones de la fiscalía (Cámara de Diputados, 2011). Por este motivo, se generaron acciones que propendían a la prudencia y solidez ante una acusación terrorista. A su vez, debido a las imputaciones de “montaje", el 8 de mayo del 2012 se decidió la creación de una comisión para investigar las actuaciones y responsabilidades de las autoridades de Gobierno, en relación al Caso Bombas, la que fue presidida por el Diputado Independiente, René Alinco. Dicho instrumento llamado Comisión Internacional Investigadora, en relación al montaje concluyó la investigación por la ausencia de antecedentes que lo presuman. Se hizo hincapié en dos aspectos: el primero, que los imputados pasaron nueve meses en la Cárcel de Alta Seguridad, acusados de terroristas y eran inocentes, y el segundo, que los verdaderos culpables están impunes.

Lo anterior, en relación a que hubo representantes del Poder Ejecutivo y Legislativo, que manifestaron la vinculación entre los acusados del Caso Bombas con acciones terroristas, que violan los derechos de las personas y siembran el temor, en un clima de tensión, sea en la Araucanía con el conflicto mapuche, como en Santiago con los imputados del Caso Bombas. Del mismo modo, se discutió tanto en la Cámara de Diputados como en la del Senado, ciertas enmiendas al proyecto de ley para introducir cambios a la legislación antiterrorista. No obstante, se evidenció que no se hace clara la relación entre anarquismo y terrorismo, sino que se establece una relación más puntual hacia los 14 detenidos, a 
ellos se enfoca la presunción terrorista, como sustentaba en la acusación de la fiscalía.

Por su parte, el diario La Segunda, relacionó anarquismo y terrorismo, a partir de lo cual destacó en sus titulares las medidas de seguridad que se efectuaron para formalizar a las personas anarquistas, y la acusación de la fiscalía (La Segunda, 17 de agosto del 2010), además de la importancia que se le da a la información entregada por los testigos protegidos del Caso Bombas, los cuales apuntan a una organización terrorista nacional (La Segunda, 20 de agosto del 2010). Son sujetos peligrosos que inclusive difunden en internet manuales para la fabricación de bombas y armas (La Segunda, 20 de agosto del 2010). La defensa a la tesis de la fiscalía llega a su paroxismo, en la sección Editorial del periódico, en la cual señalan que "se trata en conjunto de una nueva etapa de la actividad terrorista bajo distintos pretextos políticos" (La Segunda, 16 de septiembre del 2010, p. 8). Sin embargo, el 1 de junio del 2012, debió retractarse y titular "Caso Bombas: Todos los acusados fueron absueltos de los cargos por delito terrorista”, en la que se hizo hincapié en la débil sustentación de pruebas para acreditar la acusación.

En relación a la vinculación entre terrorismo y anarquismo, $E l$ Ciudadano consideró que las minorías son criminalizadas. Con el fin de la dictadura militar chilena, no se terminaron las violaciones a los derechos humanos, sino que se “inició una de las etapas más difíciles para la lucha de los grupos disidentes en el poder, al amparo del marco legal dejado por Augusto Pinochet” (El Ciudadano, marzo del 2011, p. 6), como la Ley Antiterrorista. Entonces bien, según el periódico han muerto en democracia 60 estudiantes, trabajadores y militantes a manos de carabineros, entre los que se incluyen anarquistas. Destaca las declaraciones del abogado Rodrigo Román, para el cual "se persigue el derecho a disidencia” (El Ciudadano, marzo del 2011, p. 6), si bien se muestran pruebas como llamadas telefónicas, depósitos bancarios desde el extranjero, "centros de poder", estos no son evidencia de una organización ilícita terrorista. Para el periódico, preocupa que personas inocentes pueden ser "detenidas, acusadas y criminalizadas durante meses e incluso años" (El Ciudadano, marzo del 2011, p. 6). Considera por ello que se trata de un montaje, una criminalización, persecución de la disidencia, y que, en suma, una vinculación que en el caso de los acusados no es correspondiente a la verdad de los hechos.

En otras palabras, La Segunda establece una directa relación entre la ideología anarquista y el terrorismo, mientras que el diario El Ciudadano 
considera que es una acusación que se basa en pruebas infundadas como una forma de criminalizar al movimiento anarquista. Tanto actores del Ejecutivo como del Legislativo, generan una relación puntual a las 14 personas detenidas, no asociando explícitamente a todos los anarquistas conductas terroristas.

\section{EL NUEVO ENEMIGO INTERNO}

Los medios de prensa escrita La Segunda y El Ciudadano, así como los representantes del Poder Ejecutivo y Legislativo no establecieron las particularidades de los grupos vinculados al Caso Bombas, debido a que la tesis barajada por la fiscalía, apuntaba a una organización terrorista, olvidando que eran exsubversivos y militantes del Mapu-Lautaro, la cual fue una organización política militar chilena, de carácter marxista-leninista, que surgió durante los 80 en contra de la dictadura militar, olvidó que dentro de los 14 había exmilitantes del Mapu-Lautaro, como Rodolfo Retamales, Pablo Morales y Omar Hermosilla. No interesó el trasfondo de las luchas de los acusados, sino que estos sujetos anarquistas estaban sembrando el temor en la población y destruyendo el orden democrático. En ese sentido, se plantea al anarquismo como el enemigo ideológico del siglo XXI, sustituyendo al MIR, al FPMr o al Mapu-Lautaro que durante la dictadura militar adquirieron gran protagonismo.

De esta forma, el anarquismo se ha articulado con los movimientos sociales que se manifiestan contra el sistema neoliberal: "este modelo ha generado el progresivo rechazo y levantamiento de distintos grupos sociales que se han encontrado con una respuesta del Estado que se ha manifestado en coerción y castigo" (El Ciudadano, 30 de agosto del 2010, pp. 10-11). La Ley Antiterrorista y La Ley Anti-encapuchados, son evidencias de que la forma de regular esas conductas que el Estado considera impropias y que desestabilizan el orden que ellos imponen, son medidas represivas con altas penas de presidio, que se cumplen en la Cárcel de Alta Seguridad, porque "castigar es reprobar, es acusar. Por ello la principal forma de castigo, siempre ha sido señalar al culpable, mantenerlo a distancia, aislarlo, crear un vacío a su alrededor, separarlo de los demás ciudadanos que respetan la ley" (Durkheim, citado en en Wacquant, 2010, p. 13). La cárcel se implementa como un recipiente de los deshechos sociales, de las personas que están fuera del sistema, 
como "medio organizacional para la captura y trato de una población considerada despreciable y prescindible" (Wacquant, 2010, p. 282). Como lo señala Löic Wacquant, la institución penal cumple tres funciones: neutralizar físicamente y almacenar a las fracciones excedentes que persisten en la rebelión, imponer disciplina y por último, reafirmar la autoridad del Estado y voluntad política de las élites al segregar a ciudadanos correctos de los incorrectos. La cárcel es una forma de tratar las conductas indeseables, como la de los anarquistas que se quieren rebelar al sistema.

Para la población se transmite la idea de que son siempre sujetos marginales -delincuentes de alta peligrosidad-que ponen bombas, generan destrozos a la propiedad privada y pública, algunos actúan tras una capucha, tiran piedras, insultan a la policía, otros se reúnen en estos "centros de poder" que son las casas okupas, leen a Malatesta, de gustos vegetarianos, son una red transnacional. Es la construcción del enemigo del sistema, cuya forma de desdibujarlo, es una forma de mantener estable ese orden social cuando el Estado se siente amenazado, por lo que "recurrirá a la imposición coercitiva de la legislación y a tácticas de control [...] para dispersar o para reprimir las formas colectivas de oposición al poder corporativo" (Harvey, 2007, p. 84), como el anarquismo.

\section{CONCLUSIONES}

El Caso Bombas involucró un gran entramado discursivo, apoyado de forma mediática por la prensa. Simbolizó un episodio en el cual se violaron las garantías constitucionales, del derecho a la presunción de inocencia de 14 personas acusadas de ser anarquistas y de constituir una asociación ilícita terrorista. Pareció secundario si realmente lo habían hecho, ya que se priorizó la versión de la fiscalía, con sus más de 7.000 pruebas, a cargo de Alejandro Peña, lo cual sirvió para hacer un espectáculo sobre un supuesto caso de terrorismo en Chile.

En el Poder Ejecutivo y Legislativo, hubo representantes que consideraron a estas personas imputadas, como sujetos que generaban temor en la población y sus acciones como una suerte de maquinación para generar una respuesta del Estado chileno. Se los condenó sin haber sido juzgados legalmente. A la par, en el parlamento se daba una discusión en torno al proyecto de Ley del Ejecutivo sobre legislación Antiterrorista. Se construyó un discurso, que como lo señala Teun Van Dijk, directa 
o coercitivamente impone su poder por medio de leyes, pero también indirectamente a través de una expresión (Van Dijk, 2009, p. 106).

Los medios de prensa, como La Segunda construyeron un imaginario anarquista, avalándose en la visión de la Fiscalía Metropolitana Sur, en que se hizo del caso, el "objetivo expreso de ser exhibido y visto, escrutado, devorado con los ojos: la prioridad absoluta es montar un espectáculo" (Wacquant, 2010, p. 14). Frente al cual se adoptó la postura en la que estos sujetos eran delincuentes de alta peligrosidad, que incitan a otros a generar desmanes, una red internacional de apoyo, en la cual no interesa el fundamento y la historia ideológica de estos grupos, banalizando la información, tratándoles siempre como individuos que solo desean minar el apacible orden social, por medio de acciones terroristas. Por su parte, El Ciudadano, hizo una sátira de la visión anarquista que estaba siendo criminalizada, y consideró esto como parte de un montaje, con el afán de perseguir la disidencia.

Ahora bien, lo que ocurre con el diario La Segunda, es evidencia de "la transmisión de una imagen de realidad espectacularizada, y la representación socio-política restringida” (Munizaga, citada en Garretón, et al., 1993, p. 95), que es una herencia de la dictadura militar. Dicho periódico, adoptó la visión de la fiscalía en la que los anarquistas eran una cara de la sociedad indeseable, anómala. Por ende, se entregó solo la visión condenatoria, que como lo manifiesta María Olivia Monckeberg, se asocia a una falta de pluralidad que es una "traba para la expresión libre y la discusión a fondo de temas críticos para la sociedad [...] un obstáculo para la profundización de la democracia [...] para construir una sociedad inclusiva y no excluyente" (Monckeberg, 2009, p. 7). No se dio espacio para que el lector reflexionara sobre la realidad, sino que con técnicas visuales como fotografías, frases resaltadas en negrilla y titulares rimbombantes, se impuso al lector el rechazo a los individuos acusados, se caricaturizó de forma tendenciosa la identidad de estos personajes anarquistas.

Mientras que diarios como El Ciudadano entregaron una imagen independiente de la hegemónica, en la cual los acusados eran parte de la disidencia, eran víctimas de un sistema opresor, pero como lo expresa Manuel Chaparro, son medios sujetos a la máxima, “"pobres, pocos y pequeños'. Su capacidad de incidencia social es residual, son medios militantes escasamente integrados" (Chaparro, 2012, p. 20). Es así que, los sectores marginalizados, carecen de un espacio para manifestar su parecer a la sociedad, exceptuando las instancias en que su accionar perturba, lo 
cual es la ratificación de los estereotipos, que configura la sociedad a través de medios, es decir, eso se espera de ellos.

El diario La Segunda data de 1931, pertenece a la empresa El Mercurio SAP, propiedad del magnate Agustín Edwards Eastman y es de circulación diaria. Por su parte, El Ciudadano nació en el 2005 funcionando como un diario regional, luego alcanzó circulación a nivel nacional y es parte de la Red de Medios de los Pueblos, dos visiones del mundo y del periodismo muy distintas.

Es un aspecto preocupante el hecho de que ciertos medios de comunicación sigan criminalizando a ciertos movimientos sociales en particular, y a toda la disidencia política en general, formando en la ciudadanía una imagen profundamente sesgada en términos ideológicos, confirmando así que "cuando la sociedad se opone a esta 'socialización de intereses' se recurre a las políticas del miedo y de la criminalización de la disidencia” (Velasco, 2013, p. 10).

Entonces, si bien el Poder Ejecutivo y Legislativo no desarrollaron una caracterización del anarquista como sí la efectuó La Segunda, en esa caracterización se basaban para presentar proyectos como modificaciones a la Ley Antiterrorista, mociones y discusiones en torno a ello, lo cual constituye una forma de generar miedo y criminalizar a ese otro indeseable, como un mecanismo de defensa, ante la rebeldía de un sector de la población el cual puede "contagiar" al resto de las personas con una ideología antisistema.

Por último, esta investigación se ha preocupado de estudiar los discursos que, como lo señala Norman Fairclough, el lenguaje adquiere un papel importante, debido a que se imponen nuevas representaciones del mundo, nuevos discursos y formas en su uso (Fairclough, 2000, p. 14). Los discursos de la prensa escrita, los emitidos desde el Poder Ejecutivo y del Poder Legislativo, configuran una construcción social, una cosmovisión de mundo, que corresponde a su ideología como un "conjunto de ideas, creencias, conceptos y demás, destinados a convencernos de su 'verdad', y sin embargo al servicio de un poder inconfeso" (Žižek, 2003, p. 17). Una construcción discursiva por la que se ejerce un control social sobre la población, que en el caso del anarquismo, surge como un sujeto que se opone a este orden, capaz de efectuar una violencia reactiva, posicionándose como "una parte de la población en prescindible, indeseable e inconveniente para la constitución del "mundo" (Calveiro, 2012, p. 20), que es la repuesta violenta del Estado. En otras palabras, el anarquista es presentado como un sujeto delincuente, se banaliza 
su discurso y sus acciones, se transforma en el nuevo enemigo interno, que es más bien una prolongación del sujeto subversivo que "ya no es marcadamente algún tipo político, sino el delincuente" (Ramos \& Guzmán, 2000, p. 135), y precisamente eso es lo que se intenta generar, extraer de él su componente que le otorgaría racionalidad a su actuar y exhibirlo como un bandido común.

\section{REFERENCIAS}

Anarquistas amedrentan a profesor de la 'U' y se vanaglorian de quemar bus del Transantiago. (2011, 25 de octubre). La Segunda, Sección crónica de hoy, p. 2. Anarquistas del mundo se reunieron en Suiza. (2012, agosto). El ciudadano, Sección oficio y pegas varias, p. 20.

Anarquistas se toman durante una hora embajada chilena en Grecia. Sección Política y Sociedad. (2011, 28 de marzo). La Segunda, p. 17.

Ansart, P. (1970). El nacimiento del Anarquismo. Amorrortu Editores.

Arendt, H. (2005). Sobre la violencia. Alianza Editorial.

Aróstegui, J. (1994). Violencia y política en España. Marcial Pons.

Barbero, J. (2002). La educación desde la comunicación. Editorial Norma.

Beriain, J. (2004). Modernidad y violencia colectiva. cis.

Bourdieu, P. (1999). Intelectuales, política y poder. Sobre el poder simbólico. Eudeba.

Bourdieu, P. (2012). Intelectuales, política y poder. Clave Intelectual.

Braud, P. (2006). Violencias políticas. Alianza Editorial.

Calveiro, P. (2012). Violencias de estado. La guerra antiterrorista y la guerra contra el crimen como medios de control global. Siglo xxi Editores.

Cámara de Diputados. (2011, 27 de septiembre). Proyecto de ley que fortalece el reguardo del orden público. https://media.elmostrador.cl/2011/10/Proyecto-deley-que-fortalece-el-resguardo-del-orden-p\%C3\%BAblico.pdf

Cámara de Diputados. (2012). Informe de Comisión Especial Caso Bombas. https://www.bcn.cl/datos_visualizaciones/recurso/cl/documento/635992/ seccion/akn635992-ds72-ds15/datos.html

Cappelletti, A. (1985). La ideología Anarquista. Alfadil Ediciones.

Carrié de la Puente. (2011). Caso Bombas. Criminalización de la disidencia políticocultural en los medios de comunicación de masas chilenos [Tesis de Pregrado]. Escuela de Periodismo, Universidad de Santiago de Chile.

Caso Bombas: recrean cómo desde la Cárcel de Alta Seguridad surgen nexos de anarquistas y exsubversivos. (2011, 13 de junio). La Segunda, Sección crónica de hoy, p. 6.

Con 150 carabineros resguardando, fiscalía formaliza a 15 personas por asociación ilícita terrorista y colocación de artefactos explosivos. (2010, 17 de agosto). La Segunda, Sección crónica de hoy, pp. 2-3.

Crettiez, X. (2009). Las formas de la violencia. Walduther Editores. 
Chaparro, M. (2012). Medio de comunicación y democracia. Lecciones desde América Latina. Revista de Comunicación y Ciudadanía Digital, 1(1). https:// n9.cl/llld https://doi.org/10.25267/COMMONS.2012.v1.i1.03

El Ciudadano. (2010, 30 de agosto). El ciudadano, Sección portada, pp.10-11.

El Ciudadano. (2010, septiembre). El ciudadano, p. 6.

El Ciudadano. (2010, octubre). El ciudadano, p. 11.

El Ciudadano. (2010, octubre). El ciudadano, p. 5.

El Ciudadano. (2010, noviembre). El ciudadano, p. 10.

El Ciudadano. (2011, marzo). El ciudadano, p. 6.

El Ciudadano. (2011, abril). El ciudadano, p. 6.

El Ciudadano. (2012, junio). El ciudadano, Sección columna de opinión, p. 13.

El Show de las Bombas. (2010, septiembre). El ciudadano, p. 7.

Errandonea, A. (2011). Un anarquismo para el siglo XXI. Madreselva.

Escobar, E. (2000). Lo imaginario. Entre las ciencias sociales y la historia. Fondo editorial universidad EAFIT.

Fairclough, N. (2000). Representaciones del cambio en el discurso neoliberal. Cuadernos de Relaciones Laborales, 16. Universidad Complutense.

Fiscalía Metropolitana Sur. (sf). Acusación Caso Bombas de la Fiscalía Regional Metropolitana Sur. Documento Oficial. https://www.bcn.cl/datos_ visualizaciones/recurso/cl/documento/635992/seccion/akn635992-ds72ds15/datos.html

Furiosos asistentes a tocata por detenidos del Caso Bombas dejan 4 carabineros heridos. (2010, 25 de octubre). La Segunda, Sección crónica de hoy, p. 12.

Galtung, J. (1998). Tras la violencia, 3R: reconstrucción, reconciliación, resolución. Afrontando los efectos visibles e invisibles de la guerra y la violencia. Gernika Gorgoratuz.

García, F. (1897). Resistencia y desobediencia civil. Eudema.

García, F. (2009). Senderos de Libertad. Terramar.

García, J. (2010, 14 de septiembre). Diario de Sesiones del Senado. Sesión 51 ${ }^{a}$. Cámara del Senado.

Goicovic, I. (2013). Escrita con sangre. Historia de la violencia en América Latina: siglos XIX y XX. CEIBOS.

González-Calleja, E. (2006). El fenómeno terrorista. Dastin Ediciones.

Harvey, D. (2007). Breve historia del neoliberalismo. Akal.

Hinzpeter, R. (2010, 18 de agosto). La Segunda, Sección crónica de hoy, p. 6.

Hinzpeter, R. (2010, 15 de septiembre). Diario de Sesiones del Senado. Sesión 53a, Cámara del Senado.

Hinzpeter, R. (2010, 20 de diciembre ). La Segunda, Sección crónica de hoy, p. 2.

Ibáñez, T. (2007). Actualidad del Anarquismo. Ediciones Terramar.

Instituto Libertad y Desarrollo. (2012, 8 de junio). "Caso Bombas". Impunidady reformas. https://archivos.lyd.org/other/files_mf/tp1065casobombas.pdf

Jaimes, P. (2012). Anarquismo latinoamericano y las formas de la violencia.

Pacarina del Sur, 3(10). www.pacarinadelsur.com/home/huellas-y-voces/403anarquismo-latinoamericano-y-las-formas-de-la-violencia

Keane, J. (2000). Reflexiones sobre la violencia. Alianza Editorial. 
Kropotkin, P. (2008). La moral anarquista. Libros de Anarres.

La redes globales-sentimentales-de los involucrados en el caso bombas. (2010, 20 de agosto). La Segunda, Sección crónica de hoy, p. 23.

La Segunda. (2011, 11 de agosto). La Segunda, Sección noticias de última hora, p. 39.

La Segunda. (2010, 17 de agosto). La Segunda, Sección crónica de hoy, p. 2.

La Segunda. (2010, 20 de agosto). La Segunda, Sección crónica de hoy, pp. 18-19.

La Segunda. (2010, 16 de septiembre). La Segunda, Sección editorial, p. 8.

La Segunda. (2010, 2 de noviembre). La Segunda, Sección crónica de hoy, p. 2.

La Segunda. (2010, 20 de diciembre). La Segunda, Sección crónica de hoy, p. 2.

La Segunda. (2010, 23 de diciembre). La Segunda, Sección crónica de hoy, p. 2.

La Segunda. (2011, 4 de abril). La Segunda, Sección crónica de hoy, p. 7.

La Segunda. (2011, 25 de abril). La Segunda, Sección crónica de hoy, p. 2.

La Segunda. (2011, 28 de abril). La Segunda, Sección crónica de hoy, p. 11.

La Segunda. (2011, 29 de noviembre). La Segunda, Sección crónica de hoy, p. 2.

La Segunda. (2012, 6 de marzo). La Segunda, Sección crónica de hoy, p. 5.

Malatesta, E. (1975). Socialismo y Anarquía. Editorial Ayuso.

Martínez, J., \& Muñoz, D. (2009). Aproximación teórico-metodológica al imaginario social y las representaciones colectivas: apuntes para una comprensión sociológica de la imagen. Universitas Humanísticas, (67), 207-221. http://goo.gl/YkQJaG

Massuh, V. (1984). La libertad y la violencia. Editorial Sudamericana.

Mayol, A. (2012). No al Lucro: De la crisis del modelo a la nueva era política. Debate.

Méndez, N., \& Vallota, A. (2001). Bitácora de la Utopía: anarquismo para el siglo XXI. Universidad Central de Venezuela (EBUC).

Mintz, F. (2006). Bakunin. Crítica y Acción. Libros de Anarres.

Monckeberg, M. (2009). Los magnates de la prensa. Random House Mondadori.

Munizaga, G. (1993). Las políticas culturales en los gobiernos democráticos en Chile. En Garretón, M., Sonowski, S., \& Subervaseux, B. Cultura, autoritarismo y redemocratización en Chile. Fondo de Cultura Económica.

O’Sullivan, N. (1987). Terrorismo, ideología y revolución. Alianza Editorial.

Perfil de violentos enrabiados que toman protagonismo en la movilización. (2011, 21 de octubre). La Segunda, Sección crónica de hoy, p. 10.

Quintana, J. (2010, 15 de septiembre). Diario de Sesiones del Senado. Sesión 53ª, Cámara del Senado.

Quiroga, P. (2013). Desencanto, autonomia y politización. El discurso del anarquismo en la sociedad chilena de post-dictadura (1990-2010) [Tesis de Maestría].

Universidad de Santiago de Chile.

Ramos, M., \& Guzmán, J. (2000). La guerra y la paz. Lom Ediciones.

Rapoport, D. (1985). La moral del anarquismo. Ariel.

Rodríguez, T. (2012). El terrorismo y nuevas formas de terrorismo. Espacios Públicos, 15(33), 72-95. https://www.redalyc.org/pdf/676/67622579005.pdf

Scott, J. (2013). Elogio al anarquismo. Crítica. 
Rosas, P. (2004). Rebeldía, subversión y prisión política. Crimen y castigo en la transición chilena 1990-2004. LOM Ediciones.

Silva, J. (2013). Caso Bombas. La prensa como juez ideológico: análisis crítico del discurso de la prensa escrita en Chile [Tesis de Pregrado]. Academia de Humanismo Cristiano.

Tamayo, T. (2012). Caso Bombas. La explosión en la fiscalía Sur. Lom Ediciones.

Testigos protegidos" aseguran que existen vínculos entre el Caso Bombas, la lucha mapuche y asesinato del cabo Moyano. (2011, 21 de febrero). La Segunda, Sección crónica de hoy, p. 6.

Van Dijk, T. (2000). El discurso como interacción social. Gedisa.

Uvalle, R. (2001). La institucionalidad democrática: eje articulador de la sociedad, el ciudadano y el Estado. Sociedad, ciudadanización y Estado democrático, 9-30.

Vallota, A. (2007). Reflexiones anarquistas. Revista Germinal, (3), 35-54.

Van Dijk, T. (2009). Discurso y poder. Gedisa.

Velasco, D. (2013). Fascismo social: políticas del miedo y servidumbre voluntaria ¿Qué hacer? Universidad de Deusto.

Wacquant, L. (2010). Castigar a los pobres: el gobierno neoliberal de la inseguridad social. Gedisa.

Žižek, S. (2003). Ideología: un mapa de la cuestión. Fondo Cultura Económica. 